Prepared in cooperation with the Delaware Department of Natural Resources and Environmental Control (DNREC) Water Supply Section, Groundwater Protection Branch

\title{
Occurrence and Distribution of Arsenic and Radon in Water from Private Wells in the Rancocas Aquifer, Southern New Castle and Northern Kent Counties, Delaware, 2015
}

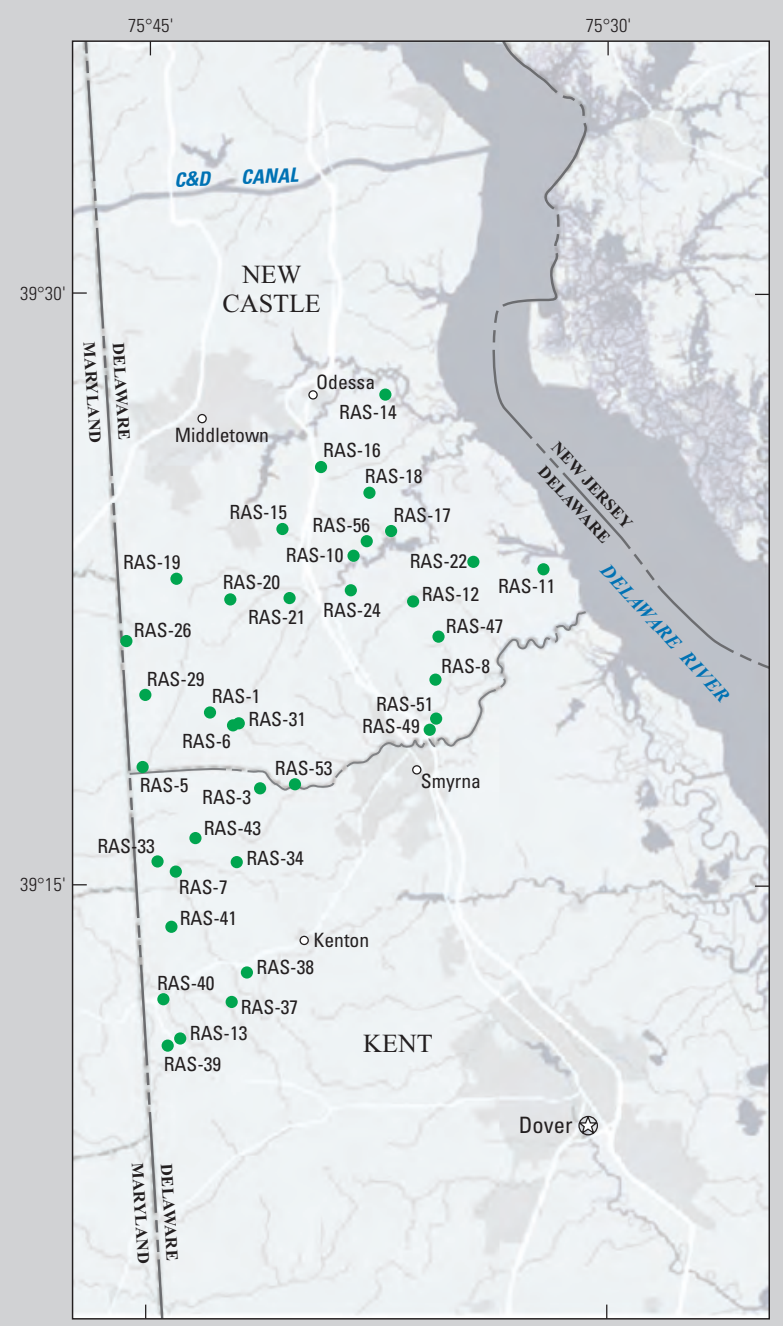

Open-File Report 2016-1143 
Cover. Study area for the Rancocas aquifer in Delaware showing sampled wells and well numbers. Refer to figure 2 . 


\section{Occurrence and Distribution of Arsenic and Radon in Water from Private Wells in the Rancocas Aquifer, Southern New Castle and Northern Kent Counties, Delaware, 2015}

By Judith M. Denver

Prepared in cooperation with the Delaware Department of Natural Resources and Environmental Control (DNREC) Water Supply Section, Groundwater Protection Branch

Open-File Report 2016-1143 


\title{
U.S. Department of the Interior SALLY JEWELL, Secretary
}

\section{U.S. Geological Survey Suzette M. Kimball, Director}

\author{
U.S. Geological Survey, Reston, Virginia: 2016
}

For more information on the USGS - the Federal source for science about the Earth, its natural and living resources, natural hazards, and the environment, visit http://www.usgs.gov or call 1-888-ASK-USGS

For an overview of USGS information products, including maps, imagery, and publications, visit http://store.usgs.gov

To order this and other USGS information products, visit http://store.usgs.gov

Any use of trade, product, or firm names is for descriptive purposes only and does not imply endorsement by the U.S. Government.

Although this report is in the public domain, permission must be secured from the individual copyright owners to reproduce any copyrighted materials contained within this report.

Suggested citation:

Denver, J.M., 2016, Occurrence and distribution of arsenic and radon in water from private wells in the Rancocas aquifer, southern New Castle and northern Kent Counties, Delaware, 2015: U.S. Geological Survey Open-File Report 2016-1143, 15 p., http://dx.doi.org/10.3133/ofr20161143.

ISSN 0196-1497 (print) ISSN 2331-1258 (online) ISBN 978-1-4113-4086-2 


\section{Acknowledgments}

Thanks are extended to the private well owners who allowed us onto their property to sample their wells and made this project possible. Funding for the U.S. Geological Survey (USGS) part of this project is provided by the U.S. Environmental Protection Agency's Drinking Water State Revolving Loan Fund 15 Percent Set Aside for Source Water Protection and was carried out through a cooperative agreement between USGS, the Delaware Department of Natural Resources and Environmental Control (DNREC), and the Delaware Geological Survey (DGS).

DNREC scientists Joshua Kasper, Amber Batille, and Anita Beckel provided considerable support for this project including an extensive database of wells in the study area, and assistance with study design, field reconnaissance of sampling sites, and obtaining permissions for groundwater sampling. Deborah Bringman, Michael Brownley, Jessica Teunis, and Mark Nardi of the USGS provided office and technical support for network design, well sampling, and database activities. 



\section{Contents}

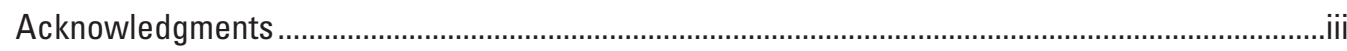

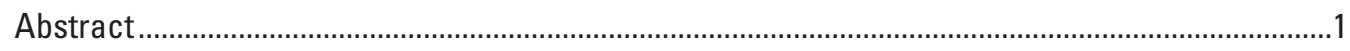

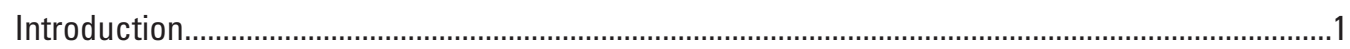

Purpose and Scope .................................................................................................... 2

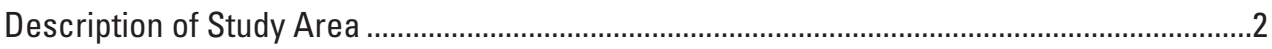

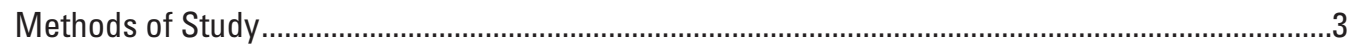

Occurrence and Distribution of Arsenic and Radon...................................................................6

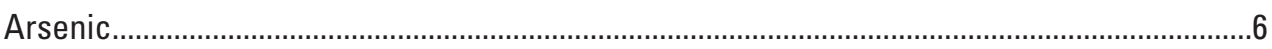

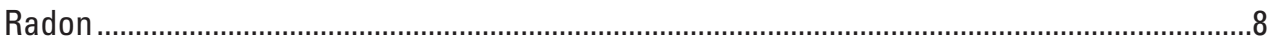

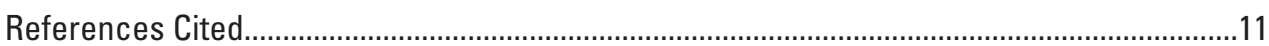

Appendix 1. Groundwater-quality data for private wells sampled in the Rancocas aquifer, Delaware, June through August 2015 ..................................................14

\section{Figures}

1. The Rancocas aquifer includes sediments of the Manasquan, Vincentown, and Hornerstown Formations in Delaware. $A$, map showing area of use of the Rancocas aquifer, and $B$, cross section showing position of geologic units in the Rancocas aquifer .

2. Maps of study area for the Rancocas aquifer in Delaware showing $A$, selection grid and the population of Rancocas aquifer wells, and $B$, sampled wells with well numbers

3. Boxplots showing range in concentrations of $A$, arsenic, and $B$, radon in water from 36 wells in the Rancocas aquifer, Delaware..

4. Map showing distribution of arsenic in water from the Rancocas aquifer, Delaware

5. Map showing combined distribution of arsenic concentrations from water in the adjacent Aquia aquifer of Maryland and the Rancocas aquifer of Delaware.

6. Map showing distribution of radon in groundwater from the Rancocas aquifer, Delaware

\section{Tables}

1. Well depths and concentrations of arsenic and radon in water from private wells in the Rancocas aquifer in Delaware sampled from June through August 2015.

2. Kendall's Tau correlation coefficients for relations between arsenic and radon with dissolved constituents or physical characteristics in groundwater from the Rancocas aquifer, Delaware 


\section{Conversion Factors}

\begin{tabular}{llll}
\hline & Multiply & \multicolumn{1}{c}{ By } & \multicolumn{1}{c}{ To obtain } \\
\hline & Length & \\
\hline foot $(\mathrm{ft})$ & 0.3048 & meter $(\mathrm{m})$ \\
mile $(\mathrm{mi})$ & 1.609 & kilometer $(\mathrm{km})$ \\
\hline
\end{tabular}

\section{Datum}

Horizontal coordinate information is referenced to the North American Datum of 1983 (NAD 83).

\section{Supplemental Information}

Temperature in degrees Fahrenheit $\left({ }^{\circ} \mathrm{F}\right)$ may be converted to degrees Celsius $\left({ }^{\circ} \mathrm{C}\right)$ as follows:

$$
{ }^{\circ} \mathrm{C}=\left({ }^{\circ} \mathrm{F}-32\right) / 1.8
$$

Specific conductance is given in microsiemens per centimeter at 25 degrees Celsius $\left(\mu \mathrm{S} / \mathrm{cm}\right.$ at $\left.25^{\circ} \mathrm{C}\right)$.

Concentrations of chemical constituents in water are given in either milligrams per liter ( $\mathrm{mg} / \mathrm{L}$ ) or micrograms per liter $(\mu \mathrm{g} / \mathrm{L})$.

Activities for radioactive constituents in water are given in picocuries per liter (pCi/L).

\section{Abbreviations}

DGS

Delaware Geological Survey

DNREC

Delaware Department of Natural Resources and Environmental Control

EPA

U.S. Environmental Protection Agency

USGS

U.S. Geological Survey 


\title{
Occurrence and Distribution of Arsenic and Radon in Water from Private Wells in the Rancocas Aquifer, Southern New Castle and Northern Kent Counties, Delaware, 2015
}

\author{
By Judith M. Denver
}

\section{Abstract}

Water samples were collected and analyzed for arsenic and radon from 36 private, mostly domestic wells that tap the Rancocas aquifer in southern New Castle and northern Kent Counties, Delaware, during the summer of 2015. Both arsenic and radon are from natural mineral sources, in particular glauconitic and other marine-derived sediments, which are important components of the geologic formations comprising the Rancocas aquifer. Routine testing of domestic wells is not required in Delaware; as a result, many homeowners are not aware of potential water-quality problems with these chemicals in their well water. Arsenic has previously been detected at levels of potential concern for human health in this aquifer in adjacent parts of Maryland where it is referred to as the Aquia aquifer. Arsenic and radon also have previously been detected in several Rancocas aquifer wells in Delaware. The Delaware Department of Natural Resources and Environmental Control intends to use the data from this project to better identify areas with potential for levels of concern for domestic well owners. This report includes chemical results and maps showing the distribution of sampled wells and concentrations of arsenic and radon. All data collected for this study also are available in the U.S. Geological Survey's National Water Information System database.

Arsenic was detected above the minimum reporting limit of 0.1 micrograms per liter $(\mu \mathrm{g} / \mathrm{L})$ in 34 of the 36 wells sampled with concentrations ranging from about 0.11 to $27 \mu \mathrm{g} / \mathrm{L}$. In 15 of the samples, arsenic concentrations were at or above the U.S. Environmental Protection Agency (EPA) Maximum Contaminant Level (MCL) of $10 \mu \mathrm{g} / \mathrm{L}$ for public wells. Most of the higher concentrations are clustered along a band running from the southwest to northeast in the southern part of the study area.

Radon, which is an inert gas derived from radium, was detected in all water samples with concentrations ranging from
85 to 1,870 picocuries per liter (pCi/L). Currently, the EPA has not set a MCL for radon in public water systems. There were no samples where radon was detected at a concentration exceeding the proposed alternative MCL of 4,000 pCi/L. Samples from 16 of 36 wells were above the lower proposed MCL of $300 \mathrm{pCi} / \mathrm{L}$. Most of these samples were from wells greater than 200 feet deep located in a similar part of the aquifer as the higher concentrations of arsenic along an eastnortheasterly line in the southern part of the study area.

\section{Introduction}

Groundwater is the sole source of potable water supply in the rapidly growing area of southern New Castle and northern Kent Counties, Delaware, where a large part of the population relies on private wells (Maupin and others, 2014). The Rancocas aquifer is an important source of water supply in this area and the quality of this resource is of growing concern. The availability of water also is of growing concern in this area, which is estimated to triple in population between 2000 and 2030 (He and Andres, 2011). Arsenic and radon are natural contaminants from geologic sources that are commonly present in groundwater. One or both of these chemicals have been detected at levels of concern in groundwater in previous analyses of water from the Rancocas aquifer in Delaware (Bachman and Ferrari, 1995; McLaughlin and Velez, 2006; A.S. Andres, Delaware Geological Survey, written commun., 2014) as well as through an extensive sampling program for arsenic in adjacent parts of Maryland, where the aquifer is referred to as the Aquia aquifer (Drummond and Bolton, 2010).

Ingestion of arsenic in drinking water can cause a variety of human health problems, including skin, liver, lung, bladder, and kidney cancer (World Health Organization, 2001). The current U.S. Environmental Protection Agency (EPA) 
Maximum Contaminant Level (MCL) for arsenic in public water systems is 10 micrograms per liter $(\mu \mathrm{g} / \mathrm{L})$. The presence of arsenic has been documented in groundwater from several wells in Delaware in the Rancocas aquifer but the issue became of greater concern when the MCL was lowered from $50 \mu \mathrm{g} / \mathrm{L}$ to $10 \mu \mathrm{g} / \mathrm{L}$ on January 23, 2006 (Federal Register, 2001). Also, recent documentation of arsenic concentrations above the new MCL in the adjacent State of Maryland (Drummond and Bolton, 2010) in the same aquifer and sampling by the Delaware Geological Survey (DGS) indicated that a similar pattern was likely in Delaware.

Radon, an inert gas derived from radium, is primarily of concern through inhalation of indoor air in living spaces after the radon degasses from water into air, which could occur in a shower, for example (National Research Council, 1999). There is currently no EPA drinking water standard for radon. Radon has two proposed drinking water standards: a proposed alternative MCL of 4,000 picocuries per liter $(\mathrm{pCi} / \mathrm{L})$ and a proposed lower MCL of $300 \mathrm{pCi} / \mathrm{L}$ (U.S. Environmental Protection Agency, 2012). A previous study in southern New Castle County found that the seven wells sampled in the Rancocas aquifer all had concentrations of radon above the proposed lower MCL of $300 \mathrm{pCi} / \mathrm{L}$, although none of the concentrations were above the higher proposed alternative MCL of 4,000 pCi/L (Bachman and Ferrari, 1995).

Although both chemicals have been previously detected in the Rancocas aquifer, the distribution of these chemicals in the use area of the Rancocas aquifer of Delaware, where many domestic wells tap this aquifer, has not been adequately determined. Whereas the quality of public water supplies is regulated under the Safe Drinking Water Act, routine sampling of domestic wells is not required and it is the homeowner's responsibility to monitor their drinking water. The results of this project will provide information to State officials that can be used to inform well owners about potential health risks from arsenic or radon. These data also will be useful in combination with other data for future studies of the distribution of aquifer lithologic and hydrochemical factors affecting the occurrence and distribution of these chemicals in groundwater.

\section{Purpose and Scope}

The purpose of this report is to document the occurrence and distribution of arsenic and radon in groundwater from wells located throughout the area of use for domestic water supply in the Rancocas aquifer in Delaware (fig. 1). Wells identified as tapping the Rancocas aquifer were sampled for arsenic and radon, along with field parameters (specific conductance, temperature, dissolved oxygen, and $\mathrm{pH}$ ), major ions, nutrients, and some trace elements. Maps showing the distribution of sampled wells and the concentrations of arsenic and radon are provided. A complete table of chemical results is included in Appendix 1 of this report. All data collected for this study also are available in the U.S. Geological Survey (USGS) National Water Information System (NWIS) database.

\section{Description of Study Area}

The study area includes the area underlain by the Rancocas aquifer from its subcrop area beneath the Columbia aquifer in southern New Castle County, Delaware near Middletown and Odessa, to the southernmost extent of the aquifer's use in northern Kent County along an east-northeasterly line from Kenton to just south of Smyrna (fig. 1). This area has been determined in previous studies to be the major area of use of this aquifer (Dugan and others, 2008; McLaughlin and Velez, 2006). The Rancocas aquifer thickens from 0 feet (ft) at its northernmost extent to over $100 \mathrm{ft}$ near Middletown where there is significant interconnection with the overlying Columbia aquifer and the Rancocas is under watertable, or semi-confined conditions (He and Andres, 2011) (fig. 1). In the southern, confined part of the aquifer, it ranges from $100 \mathrm{ft}$ thick in northeastern Kent County to $200 \mathrm{ft}$ thick in northwestern Kent County, with its top less than $100 \mathrm{ft}$ below sea level in northwest Kent County (McLaughlin and Velez, 2006).

The Rancocas aquifer is composed of glauconitic sands of marine origin that have been placed in the Manasquan (Paleocene to Eocene) and Vincentown (Paleocene) Formations and the underlying Hornerstown (Paleocene) Formation (Benson and Spoljaric, 1996; Dugan and others, 2008). The Manasquan Formation is glauconitic and shelly fine sand. In less silty locations it can function as part of the Rancocas aquifer; otherwise it functions as a leaky confining unit. The Vincentown Formation is the primary unit making up the Rancocas aquifer (Dugan and others, 2008). It is described as glauconitic sand composed primarily of medium to fine-grained quartz sand (90-95 percent) and fine-grained glauconite, and is roughly equivalent to the Aquia Formation of Drummond (1998) in Maryland (Dugan and others, 2008). Sandier facies of the Hornerstown Formation also function as part of the Rancocas aquifer. The Hornerstown Formation is composed of glauconitic sand that is silty and slightly to moderately clayey with scattered shell beds and a calcareous silt and clay matrix. Glauconite forms 90 to 95 percent of the sand fraction in the Hornerstown Formation (Dugan and others, 2008).

Both arsenic and radon are associated with glauconitic sediments (Woodruff and others, 1992; Barringer and others, 2014). In addition to glauconite, geologic materials common in marine-derived sediments that are likely to include arsenic include other phyllosilicates (such as mica and clay minerals); arsenic also is commonly associated with iron in these sediments (Barringer and others, 2014). Radon is very soluble in groundwater and usually associated with nearby enrichment of its parent element, radium, which is a decay product of uranium. Higher concentrations of radioactive elements can be concentrated in glauconite and other marine sediments such as apatite in phosphate nodules and in fossilized bone materials where uranium can substitute for calcium (Woodruff and others, 1992; Schumann, 1993). Low radon values are typically associated with non-marine fluvial and deltaic quartz sands. 


\section{Methods of Study}

The sampling network for this study was developed to obtain information on the occurrence and distribution of arsenic and radon in the area of use for drinking water of the Rancocas aquifer (fig 2). Delaware Department of Natural Resources and Environmental Control (DNREC) and USGS staff worked together to identify potential wells for sampling in the Rancocas aquifer, design the sampling network, and obtain permission for sampling. The area of use of the Rancocas aquifer was identified using the hydrogeologic framework from the DGS (Dugan and others, 2008; McLaughlin and Velez, 2006). The population of Rancocas aquifer wells in the study area, most of which were domestic, was identified by intersecting the screened intervals of wells from the DNREC well-permitting database with data grids from He and Andres (2011) representing the top and bottom of the Rancocas aquifer (fig 2a). A grid was overlain on the area of use of the aquifer in order to create an equal area distribution for sampling. A subset of 55 wells that cover the aquiferuse area both aerially and at different depths in the aquifer were selected as potential sites for sampling. Wells in each grid cell were visited to determine if the wells were suitable for sampling and to request the owner's permission. After permission for sampling was obtained, information relevant to sample collection, such as the location and type of raw water tap, was documented. Of the wells originally selected, 36 wells screened in the Rancocas aquifer were sampled (fig. 2b; table 1). Several of the wells that were initially
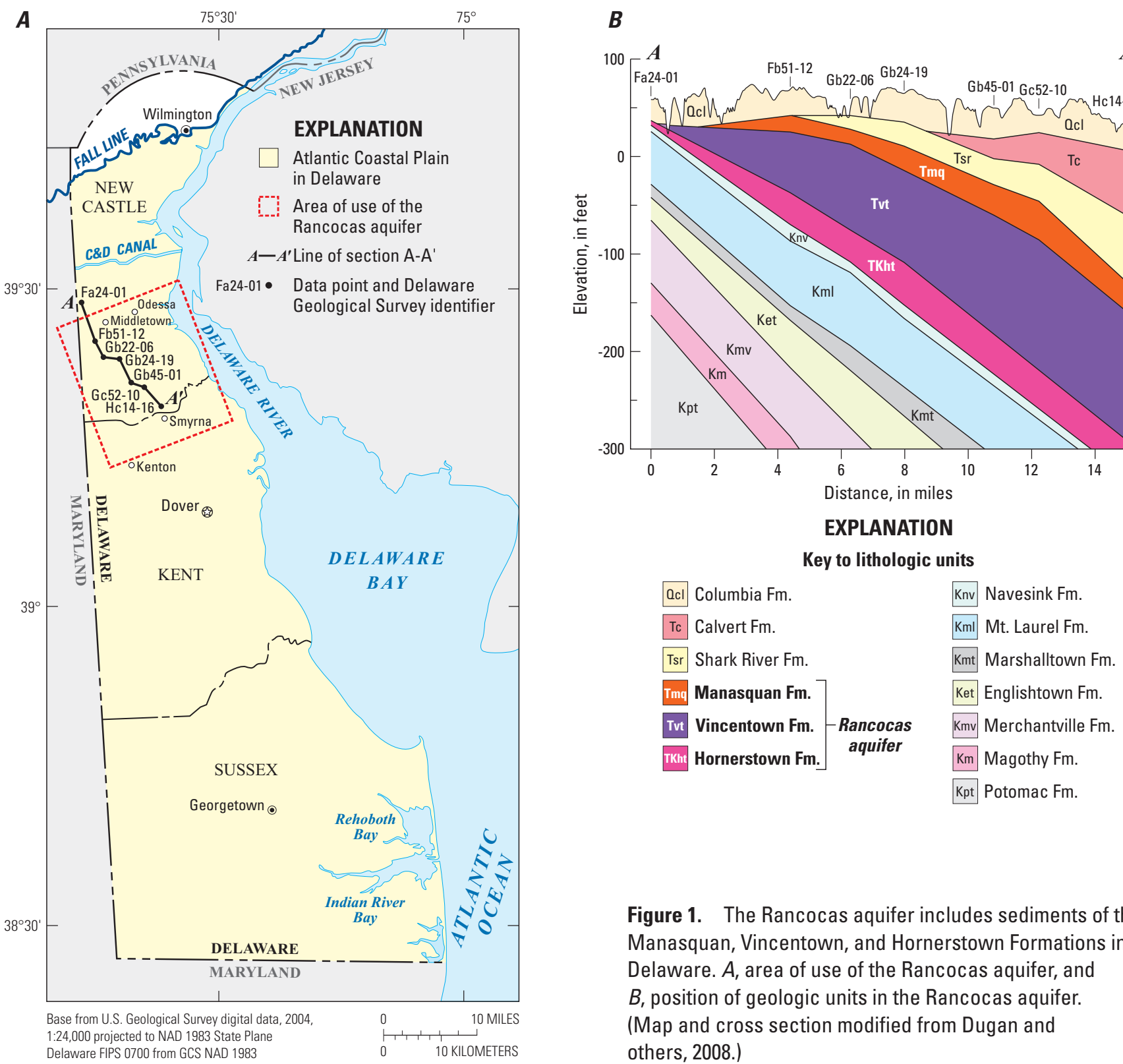

Figure 1. The Rancocas aquifer includes sediments of the Manasquan, Vincentown, and Hornerstown Formations in Delaware. $A$, area of use of the Rancocas aquifer, and $B$, position of geologic units in the Rancocas aquifer. (Map and cross section modified from Dugan and others, 2008.) 

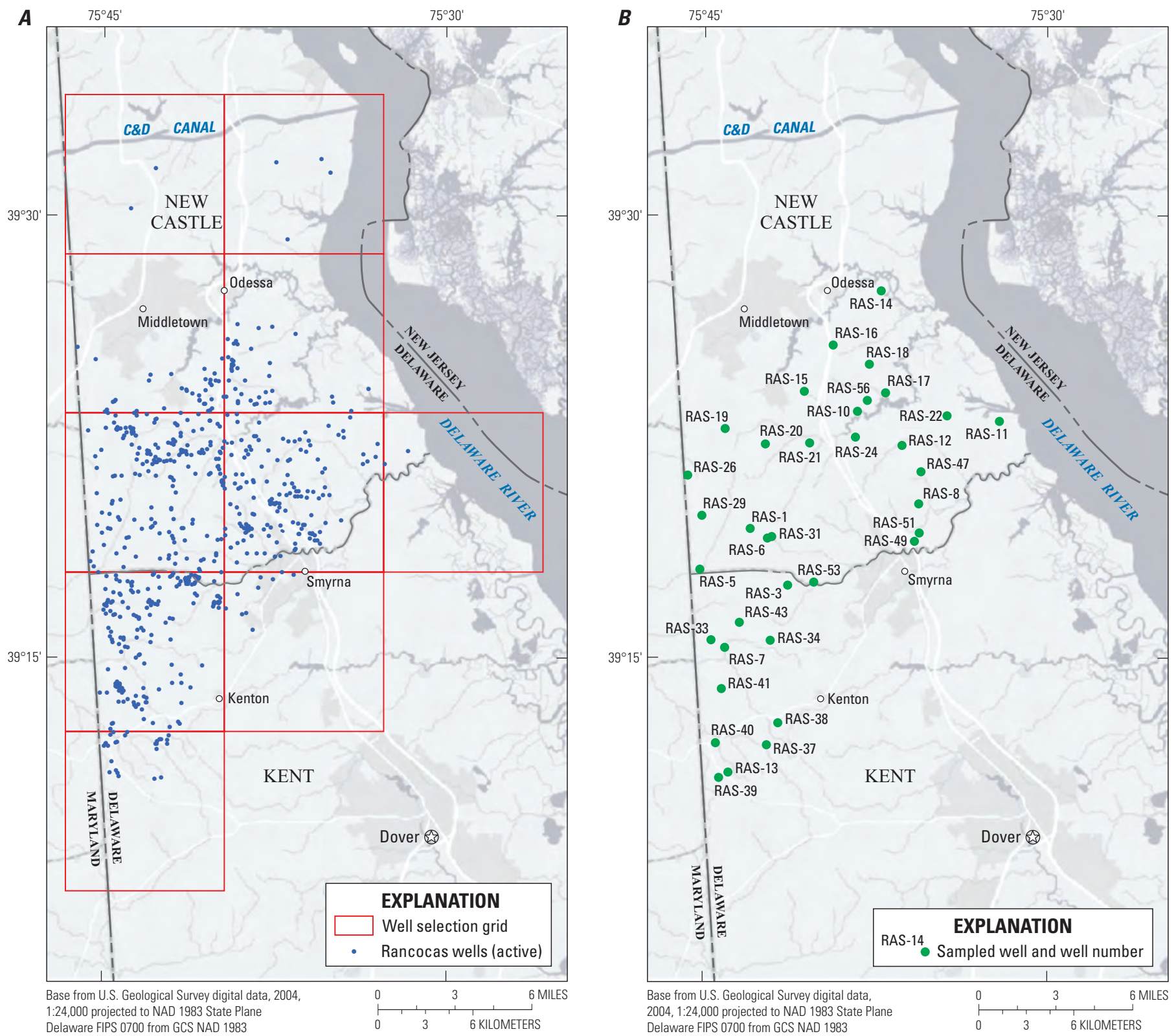

Figure 2. Study area for the Rancocas aquifer in Delaware showing $A$, selection grid and the population of Rancocas aquifer wells, and $B$, sampled wells with well numbers. 
Table 1. Well depths and concentrations of arsenic and radon in water from private wells in the Rancocas aquifer in Delaware sampled from June through August 2015. (Well locations shown on figure 2b.)

[USGS, U.S. Geological Survey; $\mu \mathrm{g} / \mathrm{L}$, micrograms per liter; pCi/L, picocuries per liter; RAS-31*, replicate sample for RAS-31; <, less than]

\begin{tabular}{|c|c|c|c|c|c|}
\hline $\begin{array}{c}\text { Local } \\
\text { well identifier }\end{array}$ & $\begin{array}{c}\text { USGS } \\
\text { site identifier }\end{array}$ & $\begin{array}{l}\text { Well depth } \\
\text { (feet) }\end{array}$ & Date sampled & $\begin{array}{l}\text { Arsenic } \\
(\mu \mathrm{g} / \mathrm{L})\end{array}$ & $\begin{array}{c}\text { Radon-222 } \\
\text { (pCi/L) }\end{array}$ \\
\hline RAS-1 & 391922075425701 & 140 & $7 / 29 / 2015$ & 14.98 & 366 \\
\hline RAS-3 & 391727075411901 & 190 & $8 / 20 / 2015$ & 25.77 & 384 \\
\hline RAS-5 & 391759075451001 & 155 & $7 / 21 / 2015$ & 11.50 & 285 \\
\hline RAS-6 & 391903075421201 & 180 & $8 / 18 / 2015$ & 15.59 & 277 \\
\hline RAS-7 & 391520075440401 & 210 & $8 / 6 / 2015$ & 27.27 & 530 \\
\hline RAS-8 & 392013075353501 & 165 & $7 / 30 / 2015$ & 3.12 & 358 \\
\hline RAS-10 & 392321075381701 & 161 & $8 / 18 / 2015$ & 0.10 & 101 \\
\hline RAS-11 & 392301075320501 & 300 & 6/11/2015 & 3.80 & 493 \\
\hline RAS-12 & 392212075362001 & 120 & $7 / 29 / 2015$ & 3.40 & 168 \\
\hline RAS-13 & 391106075435301 & 380 & $7 / 30 / 2015$ & 11.55 & 351 \\
\hline RAS-14 & 392726075371501 & 66 & $6 / 17 / 2015$ & 0.36 & 350 \\
\hline RAS-15 & 392402075403601 & 75 & $6 / 15 / 2015$ & 0.46 & 123 \\
\hline RAS-16 & 392536075392101 & 100 & $6 / 17 / 2015$ & 1.13 & 98 \\
\hline RAS-17 & 392359075370301 & 95 & 6/10/2015 & 1.34 & 138 \\
\hline RAS-18 & 392457075374601 & 135 & $8 / 24 / 2015$ & $<0.1$ & 162 \\
\hline RAS-19 & 392245075440401 & 80 & $6 / 11 / 2015$ & 0.30 & 212 \\
\hline RAS-20 & 392215075421801 & 160 & $7 / 28 / 2015$ & 0.69 & 140 \\
\hline RAS-21 & 392217075402201 & 120 & 7/7/2015 & $<0.1$ & 163 \\
\hline RAS-22 & 392312075342201 & 120 & $6 / 10 / 2015$ & 6.30 & 254 \\
\hline RAS-24 & 392228075382201 & 80 & $7 / 22 / 2015$ & $<0.1$ & 133 \\
\hline RAS-26 & 392110075454201 & 145 & 7/7/2015 & 4.03 & 127 \\
\hline RAS-29 & 391949075450501 & 118 & $6 / 24 / 2015$ & 4.88 & 223 \\
\hline RAS-31 & 391906075420101 & 142 & $6 / 24 / 2015$ & 10.18 & 85 \\
\hline RAS-31* & 391906075420101 & 142 & $6 / 24 / 2015$ & 10.35 & 90 \\
\hline RAS-33 & 391536075443901 & 258 & $7 / 8 / 2015$ & 20.15 & 126 \\
\hline RAS-34 & 391535075420401 & 260 & $7 / 21 / 2015$ & 27.23 & 484 \\
\hline RAS-37 & 391202075421301 & 360 & $7 / 13 / 2015$ & 1.68 & 366 \\
\hline RAS-38 & 391247075414401 & 355 & $7 / 22 / 2015$ & 9.96 & 396 \\
\hline RAS-39 & 391055075441901 & 360 & $8 / 19 / 2015$ & 16.29 & 580 \\
\hline RAS-40 & 391205075442801 & 300 & 7/13/2015 & 27.14 & 635 \\
\hline RAS-41 & 391356075441101 & 280 & $8 / 6 / 2015$ & 25.11 & 395 \\
\hline RAS-43 & 391611075432501 & 180 & $7 / 9 / 2015$ & 14.49 & 214 \\
\hline RAS-47 & 392119075353101 & 160 & $7 / 28 / 2015$ & 13.20 & 316 \\
\hline RAS-49 & 391857075354701 & 254 & $6 / 23 / 2015$ & 0.60 & 1,870 \\
\hline RAS-51 & 391914075353401 & 238 & $7 / 9 / 2015$ & 2.35 & 684 \\
\hline RAS-53 & 391734075401101 & 225 & $7 / 16 / 2015$ & 26.84 & 286 \\
\hline RAS-56 & 392344075375101 & 119 & $8 / 20 / 2015$ & 0.11 & 150 \\
\hline
\end{tabular}


selected were not appropriate or available to sample for a variety of reasons, including the location or availability of sample taps prior to water-treatment systems, difficulty contacting and arranging sampling dates with well owners, and in one case, misidentification of the aquifer.

Water samples were collected using standard USGS protocols for groundwater sampling for wells with permanent pumps (Koterba and others, 1995; U.S. Geological Survey National Field Manual, variously dated). Samples for arsenic, radon, major ions, some trace elements, and nutrients were analyzed at the USGS National Water Quality Laboratory (NWQL) in Denver, Colorado. Specific conductance, temperature, dissolved oxygen, and $\mathrm{pH}$ were measured in the field using a multi-parameter meter. Bicarbonate concentrations were calculated on the basis of field titrations for alkalinity (Radtke and others, 1998).

An office blank was collected prior to sampling and one replicate sample was collected and analyzed for all waterquality parameters measured to ensure quality control. The office blank was collected to ensure sample equipment and sampling methods did not cause contamination. All values for the office blank were below their respective reporting levels, with the exception of chloride, that was at the reporting level of 0.2 milligrams per liter $(\mathrm{mg} / \mathrm{L})$, which is well below any environmental concentrations. A replicate sample measures the combined precision of sampling and laboratory analysis procedures. The replicate sample had results consistent with its respective environmental sample (see Appendix 1). For arsenic and radon, the relative percent differences between replicate and environmental values were less than 2 percent and 6 percent, respectively.

After data were received from the laboratory, they were summarized in the tables and maps that are included in this report. Results from individual private wells were sent to well owners. A complete table of data is included in Appendix 1. All data collected for this project are available online in the USGS NWIS database (http://waterdata.usgs.gov/nwis). The well identification numbers listed in Appendix 1 can be used to retrieve these data.

\section{Occurrence and Distribution of Arsenic and Radon}

Arsenic and radon were widely detected in water samples from the Rancocas aquifer (table 1). Arsenic was detected above the minimum reporting limit of $0.1 \mu \mathrm{g} / \mathrm{L}$ in 34 of the 36 wells sampled with concentrations ranging from about 0.11 to $27 \mu \mathrm{g} / \mathrm{L}$ and a median concentration of about $4 \mu \mathrm{g} / \mathrm{L}$. Radon was detected in all water samples with concentrations ranging from 85 to $1,870 \mathrm{pCi} / \mathrm{L}$, with a median of about $260 \mathrm{pCi} / \mathrm{L}$. Median concentrations of both chemicals were below the $10 \mu \mathrm{g} / \mathrm{L} \mathrm{MCL}$ for arsenic and the proposed lower $300 \mathrm{pCi} / \mathrm{L}$ MCL for radon (fig. 3).

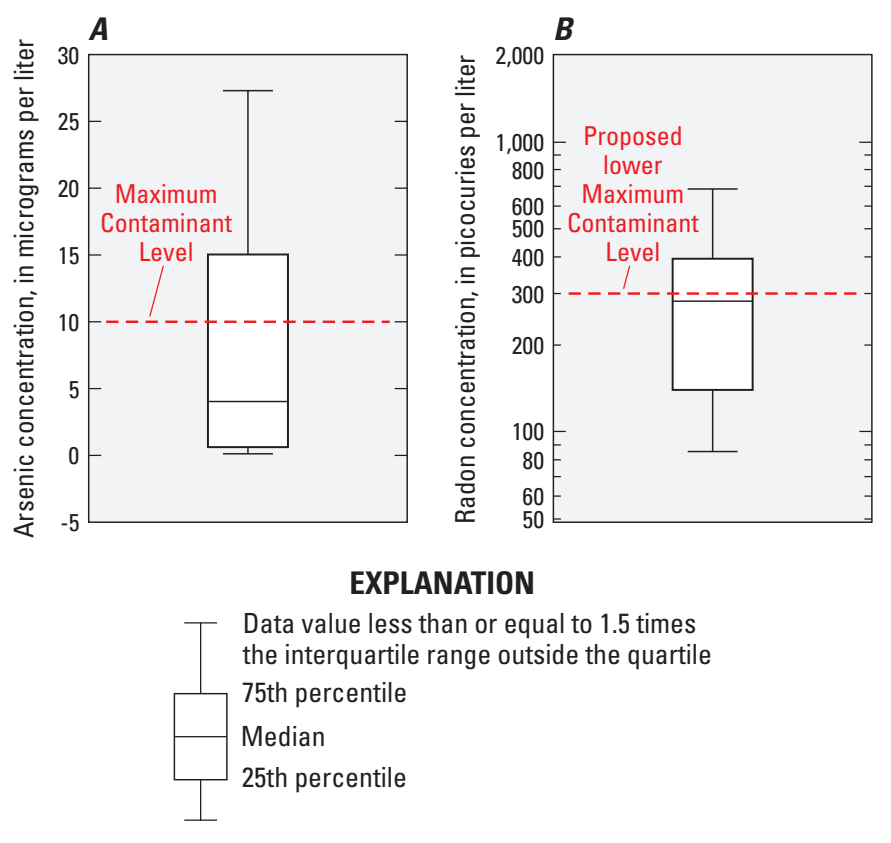

Figure 3. Range in concentrations of $A$, arsenic, and $B$, radon in water from 36 wells in the Rancocas aquifer, Delaware.

\section{Arsenic}

The concentrations of arsenic in groundwater from sampled wells were lowest in the northernmost part of the study area and highest in the southern part of the aquifer use area in a band that approximately follows the southwest to northeast strike of the geologic formations (fig. 4). With the exception of the northernmost sample (fig. 2, RAS-14), samples for this study were from confined parts of the Rancocas aquifer. Correlation coefficients between arsenic and well depth show a strong positive correlation with weaker correlations indicated between arsenic and several other dissolved constituents and characteristics (table 2). Other constituents with a positive correlation with arsenic include $\mathrm{pH}$, total dissolved nitrogen, magnesium, and potassium; arsenic is negatively correlated with orthophosphate, manganese, chloride, and silica. These potential differences in characteristics of water chemistry in relation to arsenic occurrence likely relate to the distribution of lithologic facies and hydrochemical conditions in the aquifer system.

The area with the highest arsenic concentrations is also the area with the highest reported well yields and modeled hydraulic conductivity (Dugan and others, 2008; He and Andres, 2011). Not surprisingly, the concentrations of arsenic collected for this study in Delaware follow a similar trend to the one seen in in the adjacent area of Maryland (Drummond and Bolton, 2010), and in data recently collected by DGS in the area of highest use of the Rancocas aquifer (Scott Andres, Delaware Geological Survey, written commun, 2014) (fig. 5). 


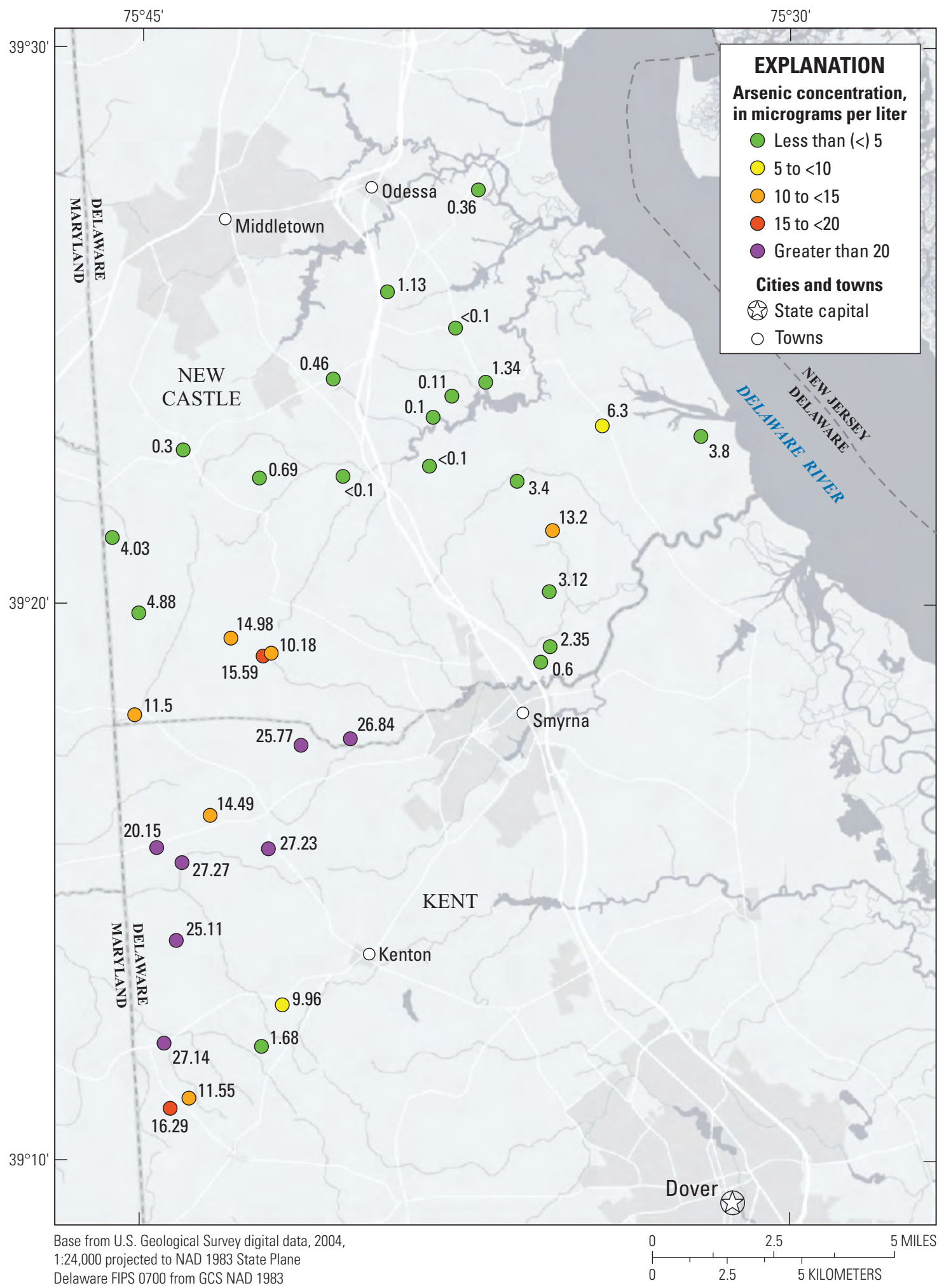

Figure 4. Distribution of arsenic in water from the Rancocas aquifer, Delaware. 
Arsenic distribution is controlled by the distribution of lithologic components related to differences in the environment of deposition of sediments that provide a potential source for arsenic, several hydrochemical mechanisms that control the mobility of arsenic, or both (Drummond and Bolton, 2010). In nearby Maryland, the coincidence of elevated arsenic concentrations with a high-energy offshore bank deposit provided evidence of lithologic controls on arsenic distribution in the Aquia aquifer (Drummond and Bolton, 2010). The extension of the area with higher arsenic concentrations in Maryland into Delaware implies that similar aquifer conditions are causing arsenic occurrence above the $10 \mu \mathrm{g} / \mathrm{L}$ MCL. Redox reactions also were thought to be an important mobilization control in the Maryland study; arsenic concentration, however, can also be affected by $\mathrm{pH}$, reductive dissolution, and competition for adsorption sites, and the precise hydrochemical control could not be determined (Drummond and Bolton, 2010).

Table 2. Kendall's Tau correlation coefficients for relations between arsenic and radon with dissolved constituents or physical characteristics in groundwater from the Rancocas aquifer, Delaware.

[Results shown in bold with $\mathrm{p}<0.01$; results shown for $\mathrm{p}<0.05$; --, indicates not significant]

\begin{tabular}{|c|c|c|}
\hline $\begin{array}{c}\text { Dissolved constituent or } \\
\text { characteristic }\end{array}$ & $\begin{array}{c}\text { Arsenic } \\
(n=36)\end{array}$ & $\begin{array}{c}\text { Radon-222 } \\
(n=36)\end{array}$ \\
\hline Depth & 0.42 & 0.46 \\
\hline Specific conductance & -- & -- \\
\hline $\mathrm{pH}$ & 0.24 & 0.39 \\
\hline Orthophosphate & -0.28 & -0.52 \\
\hline Total dissolved nitrogen & 0.23 & 0.46 \\
\hline Calcium & -- & -0.42 \\
\hline Magnesium & 0.33 & 0.42 \\
\hline Sodium & -- & 0.28 \\
\hline Potassium & 0.31 & 0.52 \\
\hline Iron & -- & -0.44 \\
\hline Manganese & -0.31 & -0.41 \\
\hline Bicarbonate & -- & -- \\
\hline Chloride & -0.31 & -0.27 \\
\hline Sulfate & -- & -0.34 \\
\hline Fluoride & -- & 0.48 \\
\hline Silica & -0.25 & -0.52 \\
\hline Aluminum & -- & -- \\
\hline
\end{tabular}

\section{Radon}

Concentrations of radon in groundwater of the Rancocas aquifer sampled for this study also showed a strong positive correlation with well depth and typically were highest in the same parts of the aquifer where arsenic concentrations were highest (fig. 6; table 2). Radon also had strong positive correlations with several other ions including $\mathrm{pH}$, total dissolved nitrogen, magnesium, potassium, and fluoride, and a weaker positive correlation with sodium. Radon had a strong negative correlation with orthophosphate, calcium, iron, manganese, and silica, and weaker negative correlations with chloride and sulfate. The occurrence of high concentrations of radioactive minerals, such as those found in glauconite and associated marine sediments such as apatite and phosphate nodules, is of primary importance in determining the potential for radon occurrence. Higher concentrations of magnesium, potassium, sodium, and fluoride in groundwater are likely associated with the glauconitic and other marine sediments. The negative correlation between radon and silica may be indicative of sediments with higher percentages of quartz sands, which are not typically associated with radioactive minerals. Correlation with other negatively charged ions, such as phosphate, iron, and manganese, also may be related to differences in aquifer mineralogy.

Water from several wells sampled in the northern part of the Rancocas aquifer by Bachman and Ferrari (1995) also had concentrations of radon similar to those in the southern part of the study area (fig. 6). Measurements of gamma radiation at the land surface in the Coastal Plain of Delaware by Woodruff and others (1992) found that the highest gamma radiation measurements were associated with the Hornerstown Formation, which subcrops in the northern part of the study area where these higher concentrations were measured (fig. 1). These results indicated that this formation was the source of the gamma radiation and, possibly, radon gas in that area. It is unknown if the higher concentrations in the southern part of the study area are related to radioactive minerals in the Hornerstown Formation. Further work comparing local lithologic knowledge would be useful for comparison to radon concentrations in the Rancocas aquifer. 


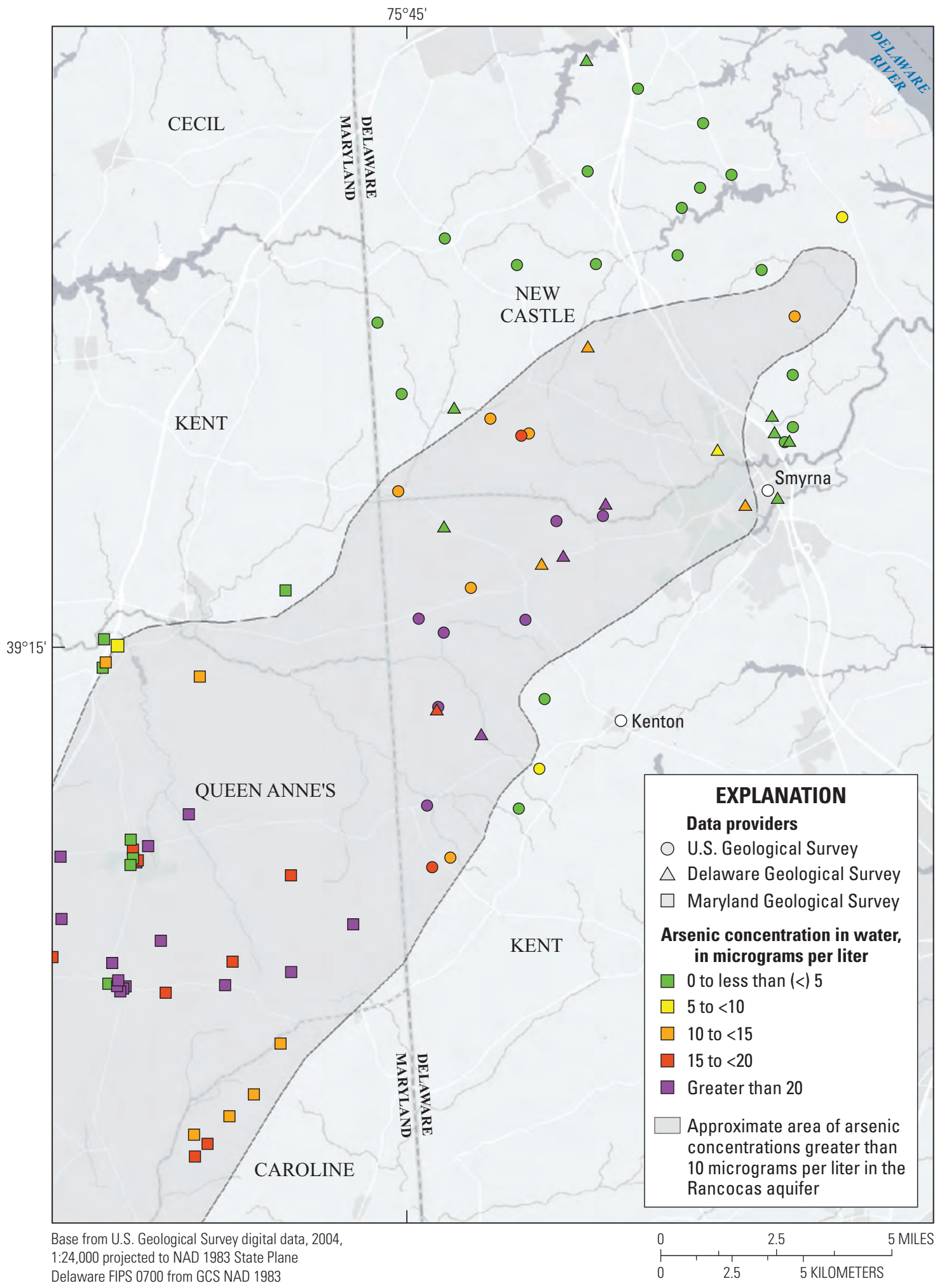

Figure 5. Combined distribution of arsenic concentrations from water in the adjacent Aquia aquifer of Maryland and the Rancocas aquifer of Delaware. 


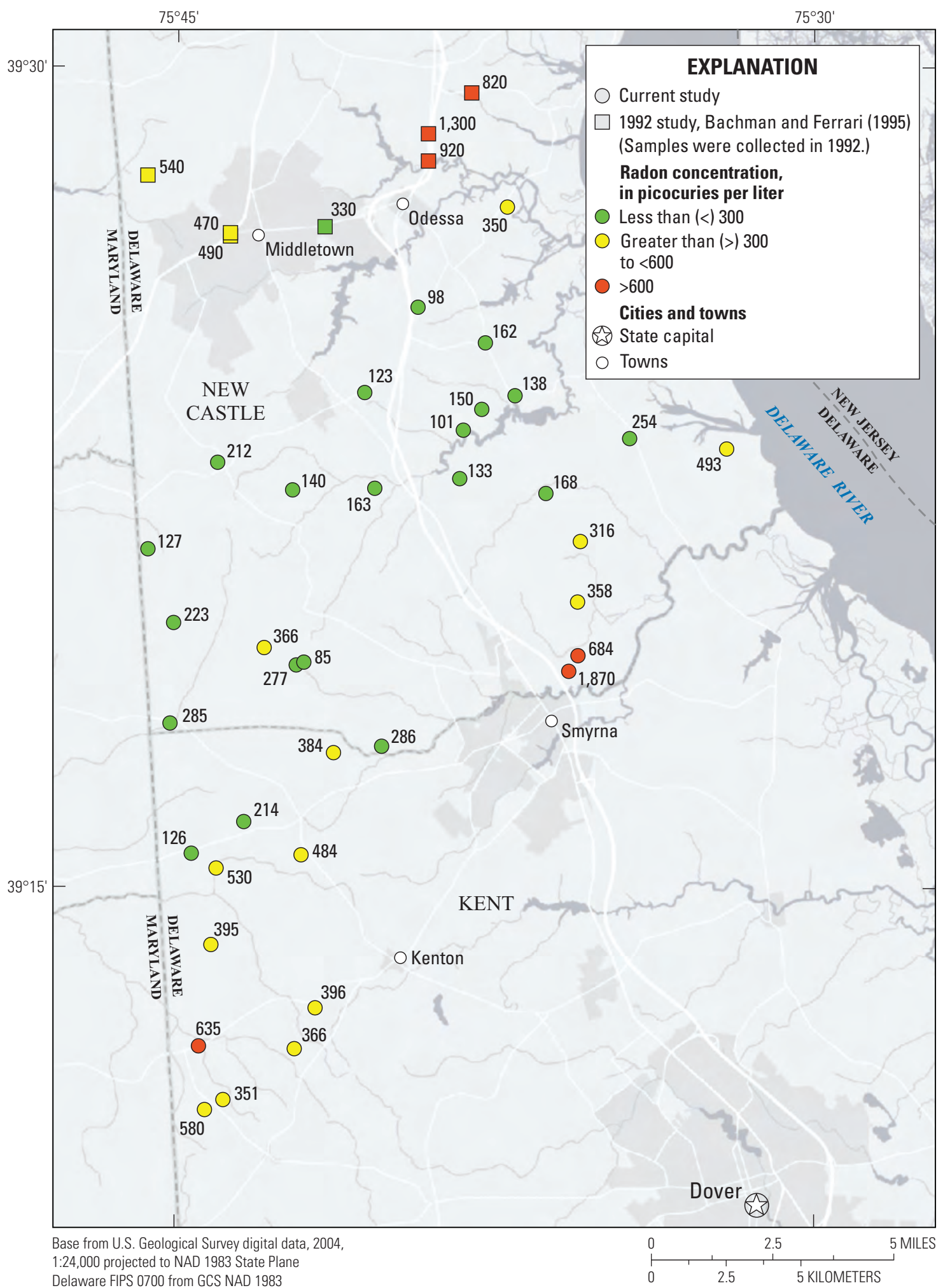

Figure 6. Distribution of radon in groundwater from the Rancocas aquifer, Delaware. 


\section{References Cited}

Bachman, L.J. and Ferrari, M.J., 1995, Quality and geochemistry of groundwater in southern New Castle County, Delaware: Delaware Geological Survey Report of Investigations No. 52, 31 p., accessed July 22, 2016, at http://www.dgs.udel.edu/publications/ri52-quality-andgeochemistry-ground-water-southern-new-castle-countydelaware.

Barringer, J.L., Reilly, P.A., Eberl, D.D., Mumford, A.C., Benzel, W.M., Szabo, Zoltan, Shourds, J.L., and Young, L.Y., 2014, Arsenic in New Jersey Coastal Plain streams, sediments, and shallow groundwater: Effects from different geologic sources and anthropogenic inputs on biogeochemical and physical mobilization processes: U.S. Geological Survey Scientific Investigations Report 2013-5107, 37 p., accessed July 22, 2016, at http://dx.doi.org/10.3133/ sir20135107.

Benson, R.N., and Spoljaric, N., 1997, Stratigraphy of the post-Potomac Cretaceous-Tertiary rocks of central Delaware: Delaware Geological Survey Bulletin No. 20, 28 p., accessed July 22, 2016, at http://www.dgs.udel.edu/ publications/b20-stratigraphy-post-potomac-cretaceoustertiary-rocks-central-delaware.

Drummond, D.D., 1998, Hydrogeology, simulation of ground-water flow, and ground-water quality of the upper Coastal Plain aquifers in Kent County, Maryland: Maryland Geological Survey Report of Investigations No. 68, 76 p.

Drummond, D.D., and Bolton, D.W., 2010, Arsenic in ground water in the Coastal Plain aquifers of Maryland: Maryland Geological Survey Report of Investigations No. 78, 72 p.

Dugan, B.L., Neimeister, M.P., and Andres, A.S., 2008, Hydrogeologic framework of southern New Castle County: Delaware Geological Survey Open File Report No. 49, 22 p., accessed July 22, 2016, at http://www.dgs.udel.edu/ publications/ofr49-hydrologeologic-framework-southernnew-castle-county.

Federal Register, 2001, The arsenic and clarifications to compliance and new source contaminants monitoring final rule: Published in the Federal Register (66 FR 6976) on January 22, 2001.

He, Changming, and Andres, A.S., 2011, Simulation of groundwater flow in southern New Castle County, Delaware: Delaware Geological Survey Report of Investigations No. 77, 18 p., accessed July 22, 2016, at http://www.dgs.udel.edu/publications/ri77-simulationgroundwater-flow-southern-new-castle-county-delaware.
Koterba, M.T., Wilde, F.D., and Lapham, W.W., 1995 , Ground-water data-collection protocols and procedures for the National Water-Quality Assessment Program: Collection and documentation of water-quality samples and related data: U.S. Geological Survey Open-File Report 95-399, 113 p., accessed July 22, 2016, at http://pubs.usgs.gov/ of/1995/ofr-95-399/.

Maupin, M.A., Kenny, J.F., Hutson, S.S., Lovelace, J.K., Barber, N.L., and Linsey, K.S., 2014, Estimated use of water in the United States in 2010: U.S. Geological Survey Circular 1405, 56 p., accessed July 22, 2016, at http:// dx.doi.org/10.3133/cir1405.

McLaughlin, P.P., and Velez, C.C., 2006, Geology and extent of the confined aquifers of Kent County, Delaware: Delaware Geological Survey Report of Investigations No. 72, 46 p., accessed July 22, 2016, at http://www.dgs. udel.edu/publications/ri72-geology-and-extent-confinedaquifers-kent-county-delaware.

National Research Council, 1999, Arsenic in drinking water: Washington, D.C., National Academy Press, 310 p.

Radtke, D.B., Wilde, F.D., Davis, J.V., and Popowski, T.J., 1998, National field manual for collection of waterquality data—Alkalinity and acid neutralizing capacity: U.S. Geological Survey Techniques for Water-Resources Investigations, book 9, chap. A6.6, 33 p.

Schumann, R.R., ed., 1993, Geologic radon potential of EPA Region 3: U.S. Geological Survey Open-File Report 93-292-C, $206 \mathrm{p}$.

U.S. Environmental Protection Agency, 2012, Report to Congress: Radon in Drinking Water Regulations, May 2012, accessed May 19, 2014, at https://archive.epa.gov/water/ archive/web/html/index-9.html.

U.S. Geological Survey, variously dated, National field manual for the collection of water-quality data: U.S. Geological Survey Techniques of Water-Resources Investigations, book 9, chaps. A1-A9, accessed July 22, 2016, at http:// water.usgs.gov/owq/FieldManual/index.html.

Woodruff, K.D., Ramsey, K.W., and Talley, J.H., 1992, Radon potential for glauconitic sediments in the coastal plain of northern Delaware, Final Report to the Delaware Department of Health and Social Services, Division of Public Health, Health Systems Protection, Radiation Control, contract no. 92-105: Newark, Delaware, Delaware Geological Survey, 43 p.

World Health Organization, 2001, Arsenic: Fact Sheet No. 372, accessed May 19, 2014, at http://www.who.int/ mediacentre/factsheets/fs372/en/. 

Appendix 1 


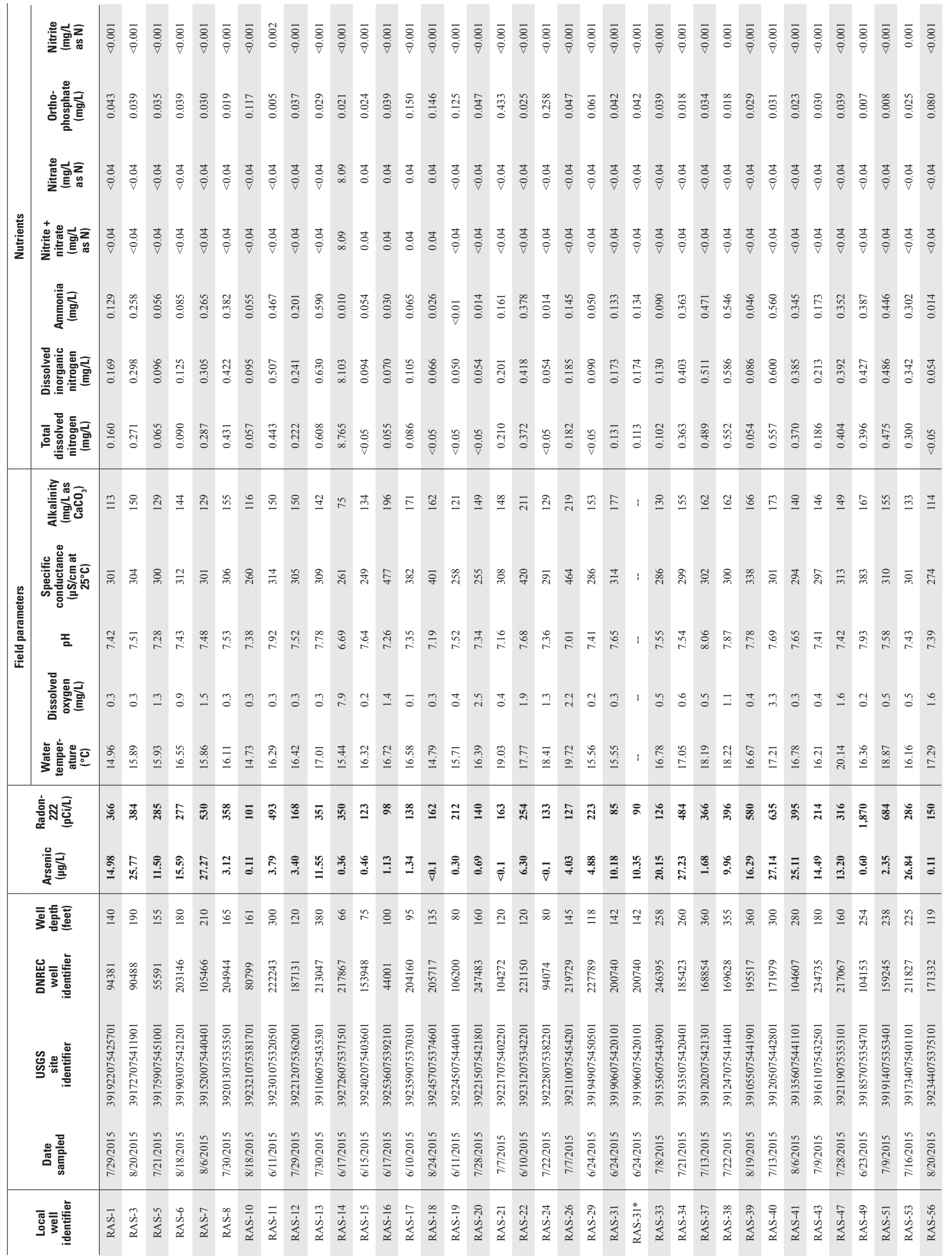




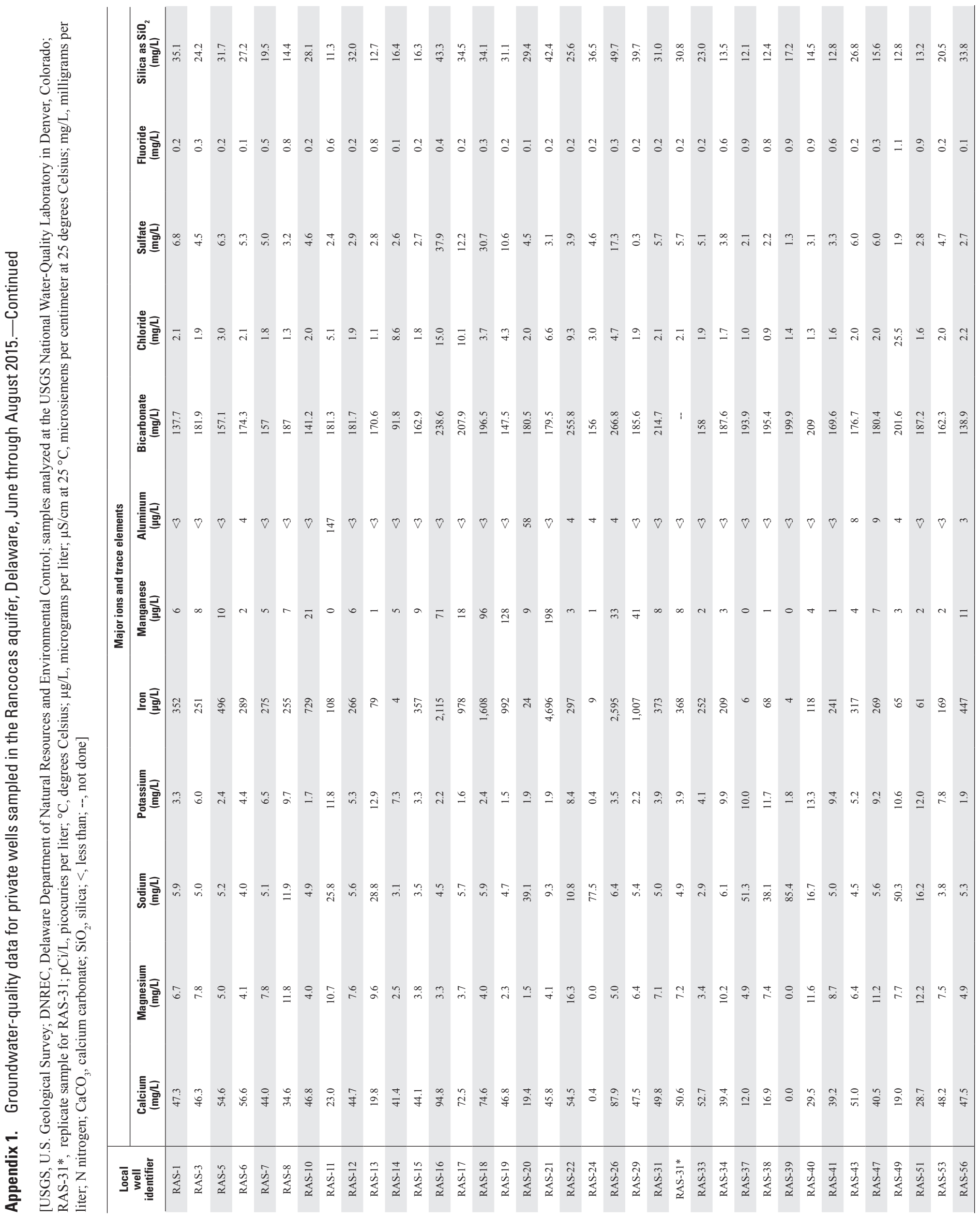



Prepared by USGS West Trenton Publishing Service Center. Edited by Valerie M. Gaine.

Graphics and layout by Timothy W. Auer.

For additional information, contact:

Director, MD-DE-DC Water Science Center

U.S. Geological Survey

5522 Research Park Drive

Baltimore, MD 21228

or visit our Web site at:

http://md.water.usgs.gov 
